\title{
DEVELOPING A TEXTBOOK OF CREATIVE POETRY WRITING BASED ON LOCAL WISDOM PROBLEM BASED LEARNING
}

\author{
Yuyun Safitri, Sarwiji Suwandi, Herman Waluyo, M. Soediro Satoto \\ IKIP of PGRI Pontianak, Indonesia \\ Email: yuyun.ikip.pgri@gmail.com
}

\begin{abstract}
The purpose of this article is to describe: (1) Condition textbook of creative writing poetry which is used in learning "Creative Writing Poetry" for the student of Indonesian Language and Literature Education in University of West Kalimantan. (2) Needs of the Student and Lecturer of Indonesian Language and Literature Education Study Program in West Kalimantan University in developing textbook if creative writing poetry based on local wisdom. Methodology which is used is research and development. Conclusions of the research result are as follow: (1) condition of the creative writing textbook which is used in earning creative writing poetry is inadequate, the detail of the book is less clear and less appropriate to the condition of the student. The poetry which is used are less attention to the face of poetry (typography), diction, imagination, concrete word, language style, rhyme/rhythm, theme/mean, feeling, tone, mandate/purpose/mean, and less attention to local wisdom. (2) Student and lecturer need a special book about creative writing poetry based on local wisdom which contains the text of poetry based on local wisdom and supporting illustration image, and also the evaluation sheet.
\end{abstract}

Keyword: Textbook of Creative Writing Poetry, Local Wisdom, Model Problem-Based Learning.

\begin{abstract}
Abstrak
Tujuan artikel ini adalah untuk mendeskripsikan: (1) Kondisi buku teks puisi penulisan kreatif yang digunakan dalam pembelajaran "Puisi Menulis Kreatif" untuk siswa Pendidikan Bahasa dan Sastra Indonesia di Universitas Kalimantan Barat. (2) Kebutuhan Mahasiswa dan Dosen Program Studi Pendidikan Bahasa dan Sastra Indonesia di Universitas Kalimantan Barat dalam mengembangkan buku teks jika kreatif menulis puisi berdasarkan kearifan lokal. Metodologi yang digunakan adalah penelitian dan pengembangan. Kesimpulan dari hasil penelitian adalah sebagai berikut: (1) kondisi buku teks tulisan kreatif yang digunakan dalam menghasilkan puisi menulis kreatif tidak memadai, detail buku kurang jelas dan kurang sesuai dengan kondisi siswa. Puisi yang digunakan kurang memperhatikan wajah puisi (tipografi), diksi, imajinasi, kata konkret, gaya bahasa, rima / irama, tema/makna, perasaan, nada, mandat/tujuan/maksud, dan kurang perhatian pada lokal kebijaksanaan. (2) Mahasiswa dan dosen membutuhkan buku khusus tentang penulisan kreatif puisi berdasarkan kearifan lokal yang berisi teks puisi berdasarkan kearifan lokal dan gambar ilustrasi pendukung, dan juga lembar evaluasi.
\end{abstract}

Kata Kunci: Buku Ajar Puisi Menulis Kreatif, Kearifan Lokal, Model Pembelajaran Berbasis Masalah 


\section{A. Introduction}

Creative Writing is a subject of Semester 4 (four) which is given in Study Program of Indonesian Language and Literature Education at IKIP PGRI Pontianak which weighs 3 credits. The subject of creative writing, include in the category of practicum course. It is as a new course based on curriculum Year of 2012. While course of Creative Writing in the Indonesian Language and Literature Education Study Program in Faculty of Teaching and Education Tanjungpura University, and STKIP Sintang, integrated to Writing course 2.

Subject Learning of Writing Creative Poetry in field of literature in IKIP PGRI Pontianak, STKIP Singkawang and STKIP Sintang contain prose, poetry, and drama. While in this research focused on creative writing poetry. Creative Writing poetry is a form of expressive productive activity. Writing skills is an important skill in the education environment especially for prospective teacher of Indonesian Language and Literature. Creative writing poetry skill not for just known, but also to be mastered and put into practice by the student as a prospective teacher. By learning the creative writing poetry, student expected to have ability to reveal or express idea, concept, opinion, mind, and feel that they have, so the power of thought, imagination, and creativity of the students can develop.

Based on information and interview result with some lecturer which is takes subject Creative Writing, student's ability of Indonesian Language and Literature Education Study Program West Kalimantan University in the creative writing poetry based on local wisdom still low. It is proven with creative writing poetry assignment which is given to some student in those several universities the result is less satisfactory. For example the students are directed to make rhymes and spells of their respective regions, the result is most of the student still lack of satisfactory. This is likely the cause is the condition of the creative writing poetry text book which is used in learning regarded as lacking in quality and quantity.

Considering the conditions and potency of the region in Indonesia which is quite diverse, so the university need to explore, increasing, and promote the potency of the region through education. Each region has privilege and local wisdom which need to be developed much better. The local wisdom can be 
utilized as a text which meant as a learn resource in learning the Creative Writing subject especially writing poetry.

Through learning creative writing poetry based on local wisdom, is expected the culture value and nation's character through activity learningteaching in order to manifest the Indonesian youth which is cultured and characterized. Therefore, lecturer needs to choose approaches model and correct learning strategy. The needs of textbook to fulfill the student's needs according to the curriculum is occupies the most important priority scale. Meanwhile, reference in the form textbook as a guidance in learning about creative writing, especially creative writing poetry based on local wisdom which used in several university in West Kalimantan felt very minimal and inadequate.

Based on the background above, so it is needed a research and development of creative writing textbook based on local wisdom. In the stage of exploration the researcher try to reveal the condition of creative writing textbook which used in learning, student and lecture's needs in developing creative writing poetry textbook based on local wisdom.

\section{B. Problem Formulation}

Research problem in this stage of exploration is formulated as below:

1. How the condition of creative writing poetry textbook which is used in the study for student of Indonesian Language and Literature Education Study Program in West Kalimantan University?

2. How the student and lecturer of Indonesian Language and Literature Education Study Program's needs in University of West Kalimantan in developing creative writing poetry textbook based on local wisdom?

\section{Purpose of Discussion}

The purpose in this exploration stage is to describe:

1. Condition of creative writing poetry textbook which is used in learning "Creative Writing Poetry" for the student of Indonesian Language and Literature Education Study Program in University of West Kalimantan. 
2. Student and lecture of Indonesian Language and Literature Education Study Program's needs in developing creative writing poetry based on local wisdom.

\section{Literature Review}

1. Textbook

According to Wibowo (2012:18) textbook is a manuscript written by lecturer in order to support main material in the subject that he taught. Wahyudi (2009:52) said that textbook is a book which used in the process of learning teaching. Textbook is also known as text book, material book, book package, or learning guidance book.

Husen (1997:187-188) reveal: Criteria of the textbook contain some aspect, there as follow: (1) Text book should be interest the student who used; (2) textbook should to able to give motivation for the student who use it; (3) contain interesting illustration for the student who utilized; (4) considering aspects of linguistic, so that in accordance with the ability of the student; (5) content should to closely related with other subject; (6) can stimulate, excite private activities of the student who used; (7) avoid equivocal and unusual concepts, so as not to confusing the student who use it; (8) having point of view which clear and assertive so also in the end become the point of view for the faithful user; (9) able to give consolidation, pressure, to the value of the children and adult; (10) appreciate personal differences for the student who use it. According to Depdikns (2003: 4-5), there are some standards of textbook writing, among others: the material in the textbook should refer to: (1) curriculum; (2) education purpose; (3) truth of material in terms of scientific aspect; and (4) conformity with the subject matter, in accordance with the student cognitive development.

Based on opinion of the experts above, can be synthesized that the textbook is a book which is published as a schoolbook in certain subject, and arranged by the expert or lecturer in that field, for the instructional means and purpose complete with learning facility which is congenial and easy to understood by the users in the schools or universities, in accordance 
to support a learning program. Good criteria of textbook attention to the characteristic are: (1) material aspects (completeness, novelty, reasoning and proof, problem solving, communication, relatedness, relatedness concept with the image, table, etc, not overlapping and contextual; (2) aspect of presentation (precondition ability; use of technology products; meaningfulness and benefits; process of knowledge formulation; visual performance); and (3) aspect of language and legibility (variety of standard language which adheres to the principles of Indonesian language and grammar; diction and shape of words, and spelling, clear, and not confusing; communicative and effective).

2. Creative Writing Poetry

Aziz, (2009:116) define writing creative activity as a write activity which is personally and does not always have practical uses. Wardoyo (2013:9) says: creative writing poetry is a productive activity which is needs certain precondition that should owned by someone who becomes poetry author. Those pre conditions consists of: (1) self motivation become poetry writer; (2) cultivate the habit of reading poetry; (3) foster sense of love for writing poetry; and (4) practice writing poetry by doing steps writing poetry consistently.

Based on opinions above, so it could be synthesized that: Creative Writing Poetry, is an expressive idea which flow from someone mind into a writing which is factually, functionally and expository, and has an original features, spontaneously, and imaginative which is pour into a form of writing poetry by involving creative, language ability, and literature ability.

3. Local Wisdom

Legislation No. 32 Year 2009 about Protection and Management of the Environment, provide understanding of local wisdom, namely the noble values prevailing in the society order of life to among others protect and managing the environment sustainably. Zulkarnain and Febriamansyah (2008:72) confirmed that: local wisdom in the form of certain principles and ways that adopted, understood, and applied by local society in the interacted and interrelated with the environment and transformed in the 
form of value system and custom norm. Kongpasertamom (2007:2) opine that local wisdom refers to knowledge which comes from a community experience and accumulation of local knowledge.

Based on some definition above, could be synthesized that local wisdom is some forms of traditions and culture that contain noble values which is done and adopted by the society and inherited from generation to generation in the society environment of certain region. Through lening of creative writing poetry based on local wisdom the student expected to having and inheriting the tradition and culture which is contain noble values that is done and embraced by the society and also inherited generation to generation in the society environment.

4. Learning Model Problem Based Learning

According to Arrends (2001:350) Learning model of Problem based learning is a learning model which is based on numbers of problem which needs authentic investigation that is investigation which needs real solving from the real problem. According to Mulyasa (2014:144-145) Problem Base learning is a learning model which purposed to stimulate the student to learn by various real life problem in daily life, related with science which is learned. According to Arrends (2001:350) Purpose of Problem Based Learning are: (1) for thinking skills and problem solvers. (2) Adult's role model. (3) make the students become learner who autonomous and independent.

Based $\mathrm{n}$ the two opinions above, so it could be synthesized that learning is an approach of learning where the student doing authentic problem with the purpose to arrange their own knowledge, developing inquiry and thinking skills more high level, developing independency and confidence. The purposes are: (1) to train student's thinking skills in order to solve the problem (2) helping the students performing in the situation of real life and push the student to cooperation in finish the task, understanding important role from mental activity and learn what was happen outside the campus, and also increasing lifelines of the student through investigation against various problems, that allow the student 
interpreting and explaining real world and build understanding about that phenomena; (3) make the student become learner who autonomous and independent.

\section{E. Method}

The research of methodology which is used is Research and Development. Subject of this research are 62 persons consists of 40 persons are students which are divided to 10 persons are students from STKIP Singkawang, 10 persons re students from STKIP Sintang and 20 persons are students from IKIP PGRI Pontinak, and from the recapitulation result of this research through questionnaire which are given to 12 lecturers from those three universities in West Kalimantan divided to 6 persons are lecturers from STKIP Sintang, 2 persons re lecturers from STKIP Singkawang, 2 persons are lecturer's from IKIP PGRI Pontianak. This stage of research lasted approximately 10 months thereare April 2015 - January 2016.

\section{F. Result}

1. Condition of creative writing textbook which is used in study

a. Result of the research through questionnaire which is given to the student

1) $75 \%$ of the respondent argue that the availability of creative writing poetry textbook in the Campus library is inadequate

2) $67,5 \%$ respondent argue, details of material which is used is less appropriate to the needs,

3) $70 \%$ respondents argue language which is used less clear to understand,

4) $62,5 \%$ respondents argue that the language which is used less appropriate with the student condition,

5) $65 \%$ respondents argue that poetry which issued less attention to the local wisdom

b. Result of the research through questionnaire which is given to the lecturer

1) $91,7 \%$ respondents argue that availability of creative writing poetry textbook in the Campus Library is inadequate, 
2) $100 \%$ respondents argue that details of material which available less appropriate to the student's condition,

3) $66,7 \%$ respondents that language which is used less clear to understand,

4) $75 \%$ respondents argue that poetry which is used less appropriate with the student's condition,

5) $66,7 \%$ respondents argue that the poetry which is used less attention inspiration of poetry (typography),

6) $66,7 \%$ respondents argue that the poetry which is used less attention to diction,

7) $83,3 \%$ respondents argue that the poetry which is used less attention to imagination,

8) $775 \%$ respondents argue that the poetry which is used less attention to concrete words,

9) $66,7 \%$ respondents argue that the poetry which is used less attention to language style,

10) There are $58,3 \%$ respondents argue that the poetry which is used less attention to rhyme/rhythm,

11) $58,3 \%$ respondents argue that the poetry which is used less attention to theme/mean,

12) $58,3 \%$ respondents argue that the poetry which is used less attention to feeling,

13) $50 \%$ respondents argue that the poetry which is used less attention to tone,

14) $83,3 \%$ respondents argue that the poetry which is use less attention to mandate/purpose/meaning,

15) $58,3 \%$ respondents argue that the poetry which is used less attention to local wisdom

Based on result of the research through questionnaire conclude as below:

a. Availability of creative writing textbook in the three universities in West Kalimantan inadequate.

b. Details of the material less appropriate to the needs. 
c. Language which is used less clear and less appropriate with the student's condition.

d. Poetry which is used less attention to inspiration of poetry (typography), diction, imagination, concrete words, language style, rhyme/rhythm, theme/mean, feeling, tone, mandate/purpose/meaning, and less attention to local wisdom.

2. The needs of the student and lecturer in developing creative writing poetry textbook based on local wisdom with problem based learning model

a. Student's need

Result of the research through questionnaire is as below:

1) $77,5 \%$ respondents strongly agree if there is special book which discuss about creative writing poetry based on local wisdom.

2) $90 \%$ respondents argue need an example text of poetry based on local wisdom.

3) $32,5 \%$ respondents argue that illustration of supporting image in the creative writing poetry textbook is necessary. $37,5 \%$ respondents argue quite necessary, the rest $30 \%$ respondents think less necessary.

4) $45 \%$ respondents think that evaluation sheet is necessary. $22,5 \%$ respondents thinks quite necessary. $10 \%$ respondents think less necessary. $22,5 \%$ respondents think not necessary.

b. Lecturer's need

Result of the Research through questionnaire is as below:

1) $83,3 \%$ respondents strongly agree if there is special book which discuss about creative writing poetry based on local wisdom.

2) $66,7 \%$ respondents argue need an example text of poetry based on local wisdom.

3) $66,7 \%$ respondents argue that illustration of supporting image in the creative writing poetry textbook is less necessary.

4) $58,3 \%$ respondents think evaluation sheet in the creative writing poetry textbook is necessary. 
Based on result of the research so it can be conclude that the student either the lecturer need special book about creative writing poetry based on local wisdom, which is contain example text of poetry based on local wisdom and contain illustration supporting image and evaluation sheet.

\section{G. Conclusion}

Based on the result of the research it can be conclude as below:

1. Condition of creative writing textbook which is used in learning creative writing poetry is inadequate, details of material less clear and less appropriate with the student's condition. Poetry which is used less attention inspiration of poetry (typography), diction, imagination, concrete words, language style, rhyme/rhythm, feeling, tone, mandate/purpose/mean, and less of local wisdom.

2. Student or lecturer needs special book about creative writing poetry based on local wisdom and illustration supporting image, and also evaluation sheet.

\section{References}

Arends, R., Wenitzky, N.E, \& Tabbenboun, M.D. 2001, Exploring Teaching An Introduction.New York: The Mc Graw-Hill Company.

Aziz, Rahmat. 2009, Karakteristik Pribadi Kreatif dan Kemampuan Menulis Kreatif, Anima, Indonesian Psychological Journal 2009, Vol. 24, No. 2.

Departemen Pendidikan Nasional. 2003, Standar Penilaian Buku Pelajaran Bahasa dan Sastra Indonesia, Jakarta: Pusat Perbukuan Departemen Pendidikan Nasional.

Husen, Akhlan. 1997, Telaah Kurikulum dan Buku Teks Bahasa Indonesia. Jakarta: Depdikbud.

Kongprasertamorn, K. 2007. Local wisdom, environmental protection and community development: the clam farmers in Tabon Bangkhusai, Phetchaburi

Mulyasa, H. E. 2014. Guru dalam Implementasi Kurikulum 2013, Bandung: Remaja Rosdakarya.

Undang-undang Republik Indonesia Nomor:32 Tahun 2009 tentang Perlindungan dan Pengelolaan Lingkungan Hidup, Yogyakarta: Pustaka Yustisia

Wahyudi, Johan. 2009. Menulis untuk Masa Depan, Sunday 22 March 2009 (05:52).

Wardoyo, Sigit, Mangun. 2013, Teknik Menulis Puisi Panduan Menulis Puisi untuk Siswa, Mahasiswa, Guru dan Dosen, Yogyakarta: Graha Ilmu.

Wibowo, Wahyu. 2012. Menulis Buku Ajar Perguruan Tinggi, Jakarta: Bidik Phronesis Publishing. 
Zulkarnain, A.Ag.,\& Febriamansyah, R. 2008. Kearifan Lokal dan Pemanfaatan dan Pelestarian Sumberdaya Pesisir. Jurnal Agribisnis Kerakyatan, 1, 